\title{
DETERMINAN HIPERTENSI PADA LANJUT USIA
}

\section{DETERMINANTS OF HYPERTENSION IN ELDERLY}

\author{
Lusiane Adam \\ Kesehatan Poltekkes Kemenkes Gorontalo \\ Kontak Penulis: lusiane.adam@yahoo.com
}

\begin{abstract}
ABSTRAK
Pada umummya semakin bertambahnya usia maka semakin besar pula risiko terjadinya Hipertensi. Hal tersebut disebabkan oleh perubahan struktur pembuluh darah seperti penyempitan lumen, serta dinding pembuluh darah menjadi kaku dan elastisitasnya berkurang sehingga meningkatkan tekanan darah. Penelitian ini bertujuan untuk mengetahui determinan penyakit Hipertensi pada lansia di Puskesmas Kota Barat Kota Gorontalo. Jenis penelitian deskriptif kuantitatif pendekatan cross sectional study. Variabel bebas adalah determinan dan variabel terikat adalah Hipertensi pada lansia. Sampel yakni seluruh lansia di wilayah kerja Puskesmas Kota Barat Kota Gorontalo pada bulan Desember 2018 sebanyak 45 orang, teknik sampel proportionate stratified random sampling. Data dianalisis menggunakan uji chi square. Penelitian ini menemukan bahwa determinan yang berkorelasi paling kuat yakni usia dan merokok. Kesimpulan; Faktor determinan yang berkorelasi paling kuat terhadap penyakit Hipertensi pada lansia di Puskesmas Kota Barat Kota Gorontalo adalah usia dan merokok. Usia memang tidak dapat dicegah lagi, akantetapi dengan pola hidup yang baik dan menghindari rokok setidaknya dapat mengurangi risiko terjadinya Hipertensi.
\end{abstract}

Kata kunci: determinan; Hipertensi; lansia

\section{ABSTRACT}

In general, the more you age, the greater the risk of hypertension. This is caused by changes in the structure of blood vessels such as narrowing of the lumen, and the walls of blood vessels become stiff and reduced elasticity thereby increasing blood pressure. This study aims to determine the determinants of hypertension in the elderly in the City Health Center of the City of Gorontalo. This type of research is a quantitative descriptive cross-sectional study approach. The independent variable is the determinant and the dependent variable is hypertension in the elderly. The sample is that all elderly in the working area of the City of West Gorontalo Health Center in December 2018 was 45 people, proportionate stratified random sampling technique. Data were analyzed using the chi-square test. This study found that the determinants that correlated most strongly were age and smoking. Conclusion; The determinant factors that correlate most strongly with hypertension in the elderly in the City Health Center in Kota Gorontalo are age and smoking. Age can not be prevented anymore, but with a good lifestyle and avoiding smoking can at least reduce the risk of hypertension.

Keywords: determinant; Hypertension; elderly 


\section{PENDAHULUAN}

Komposisi penduduk tua bertambah dengan pesat baik di negara maju maupun negara berkembang, hal ini disebabkan oleh penurunan angka fertilitas (kelahiran) dan mortalitas (kematian), serta peningkatan angka harapan hidup (life expectancy), yang mengubah struktur penduduk secara keseluruhan. Proses terjadinya penuaan penduduk dipengaruhi oleh beberapa faktor, misalnya: peningkatan gizi, sanitasi, pelayanan kesehatan, hingga kemajuan tingkat pendidikan dan sosial ekonomi yang semakin baik. Secara global populasi lansia diprediksi terus mengalami peningkatan (Kemenkes RI, 2017).

Peningkatan jumlah lansia memberikan suatu perhatian khusus pada lansia yang mengalami suatu proses menua. Permasalahan-permasalahan yang perlu perhatian khusus untuk lansia berkaitan dengan berlangsungnya proses menjadi tua, yang berakibat timbulnya perubahan fisik, kognitif, perasaan, sosial, dan seksual (Azizah, 2011).

Salah satu perubahan yang terjadi pada lansia yakni perubahan pada sistem kardiovaskuler yang merupakan penyakit utama yang memakan korban karena akan berdampak pada penyakit lain seperti Hipertensi, penyakit jantung koroner, jantung pulmonik, kardiomiopati, stroke, gagal ginjal (Fatmah, 2010).

Hipertensi atau tekanan darah tinggi adalah suatu peningkatan abnormal tekanan darah dalam pembuluh darah arteri secara terus-menerus lebih dari suatu periode. Menurut WHO, batasan tekanan darah yang masih dianggap normal adalah 140/90 mmHg, sedangkan tekanan darah $\geq 160 / 95 \mathrm{mmHg}$ dinyatakan sebagai Hipertensi. Tekanan darah di antara normotensi dan Hipertensi disebut borderline hypertension (Garis Batas Hipertensi). Batasan WHO tersebut tidak membedakan usia dan jenis kelamin (Udjianti, 2010).

Prevalensi Hipertensi yang tinggi tidak hanya terjadi di negara maju tetapi juga di negara berkembang seperti di Indonesia. Berdasarkan hasil Riset Kesehatan Dasar (RISKESDAS) tahun 2018 menunjukkan angka prevalensi Hipertensi hasil pengukuran mencapai 34,1\% meningkat tajam dari 25,8\% pada tahun 2013, dengan angka prevalensi tertinggi di Provinsi Kalimantan Selatan sebesar 44,1\% dan terendah di provinsi Papua sebesar 22,2\%. Provinsi Gorontalo sendiri pada hasil Riskesdas 2013 mencapai 29,0\% dan pada Riskesdas tahun 2018 menjadi 31,0\% dan berada pada urutan ke 20 dari 34 Provinsi (Kemenkes RI, 2018).

Berdasarkan data dari Puskesmas Kota Barat didapatkan bahwa pada tahun 2015 tercatat 618 kasus Hipertensi, tahun 2016 terdapat 683 kasus dan pada tahun 2017 tercatat terjadi 698 kasus Hipertensi serta pada tahun 2018 bulan Januari sampai dengan Oktober tercatat jumlah penduduk di wilayah kerja Puskesmas Kota Barat sebanyak 14.142 jiwa. Sementara itu jumlah kasus Hipertensi yang terjadi sebanyak 395 kasus dan menempati peringkat ke 6 pada 10 penyakit menonjol sampai dengan bulan Agustus 2018. Data Prolanis menunjukkan bahwa terdapat 83 orang lansia penderita Hipertensi di wilayah kerja Puskesmas Kota Barat (Puskesmas Kota Barat, 2018).

Beberapa faktor yang dapat menyebabkan Hipertensi antara lain kebiasaan hidup atau perilaku kebiasaan mengkonsumsi natrium yang tinggi, kegemukan, stres, merokok, dan minum alkohol (Padila, 2013). Adapun tingginya prevalensi Hipertensi menurut dikarenakan gaya hidup yang tidak sehat seperti kurangnya olahraga/aktivitas fisik, kebiasaan merokok, dan mengkonsumsi makanan yang tinggi kadar lemaknya (Ainun, Sidik, \& Rismayanti, 2014).

Obesitas dapat memicu terjadinya Hipertensi akibat terganggunya aliran darah. Dalam hal ini orang dengan obesitas biasanya mengalami peningkatan kadar lemak dalam darah (hiperlipidemia) sehingga berpotensi menimbulkan penyempitan pembuluh darah (atersklerosis). Penyempitan terjadi akibat penumpukan plak ateromosa yang berasal dari lemak. Penyempitan tersebut memicu jantung untuk bekerja memompa darah lebih kuat agar kebutuhan oksigen dan zat lain yang 
dibutuhkan oleh tubuh dapat terpenuhi. Hal inilah yang menyebabkan tekanan darah meningkat (Sari, 2017).

Kegiatan fisik yang dilakukan secara teratur dapat menyebabkan perubahan-perubahan misalnya jantung akan bertambah kuat pada otot polosnya sehingga daya tampung besar dan konstruksi atau denyutannya kuat dan teratur, selain itu elastisitas pembuluh darah akan bertambah karena adanya relaksasi dan vasodilatasi sehingga timbunan lemak akan berkurang dan meningkatkan kontrksi otot dinding pembuluh darah tersebut (Marliani \& Tantan dalam Karim, 2018).

Konsumsi garam berlebihan dapat menyebabkan peningkatan tekanan darah. Garam membantu menahan air dalam tubuh. Dengan begitu, akan meningkatkan volume darah tanpa adanya penambahan ruang. Peningkatan volume tersebut mengakibatkan bertambahnya tekanan di dalam arteri. Penderita Hipertensi hendaknya mengkonsumsi garam tidak lebih dari $100 \mathrm{mmol} / \mathrm{hari}$ atau 2,4 gram natrium, 6 gram natrium klorida (Widyanto dkk, 2013)

Rokok mengandung berbagai zat kimia berbahaya seperti nikotin dan karbon monoksida. Zat tersebut akan terisap melalui rokok sehingga masuk ke aliran darah dan menyebabkan kerusakan lapisan endotel pembuluh darah arteri sehingga mempercepat aterosklerosis. Bagi penderita yang memiliki aterosklerosis atau penumpukan lemak pada pembuluh darah, merokok dapat memperparah kejadian Hipertensi (Sari, 2017).

Penelitian sebelumnya yang dilakukan oleh (Buheli \& Usman, 2019) yang berjudul faktor determinan kepatuhan diet penderita Hipertensi hanya tertuju kepada pengaturan pola makan yang khusus sehingga tidak dapat menerangkan apa yang menjadi patokan untuk menentukan faktor apa yang paling menentukan kejadian Hipertensi, sehingga keunggulan dari artikel penelitian terbaru ini lebih berorientasi kepada apa yang menjadi penyebab hipetensi daripada pengaturan pola makan.

Hipertensi sebenarnya merupakan penyakit yang bisa diatasi dengan perilaku hidup sehat. Seorang dapat menghindari penyakit tersebut apabila dapat mengontrol pola makan, pola istirahat, pola aktivitas dengan baik dan juga menghindari hal-hal yang dapat merusak kesehatan semisal merokok, begadang, maupun makan makanan yang dapat memacu penyakit Hipertensi.

\section{METODE PENELITIAN}

Setelah dilakukan analisis bivariat antara variabel yang termasuk faktor determinan dengan variabel kejadian Hipertensi pada lansia di wilayah kerja Puskesmas Kota Barat Kota Gorontalo, maka didapatkan hasil sebagai berikut :

1. Faktor Usia

Presentase kelompok usia yang menderita Hipertensi lebih tinggi pada kelompok manula yakni sebesar $81 \%$ dibandingkan kelompok usia lansia yakni 37,5\%. Hasil analisis dengan menggunakan uji chi square test didapatkan nilai $\chi 2$ hitung 8,668 dan nilai $\rho 0,003$. Dengan pemenuhan hipotesis bahwa $\chi 2$ hitung $>\chi 2$ tabel $(8,668>2,705)$ dan nilai $\rho<\alpha(0,003<0,1)$, maka Ha diterima dan $\mathrm{HO}$ ditolak dengan demikian berarti usia merupakan faktor determinan penyakit Hipertensi pada lansia di Puskesmas Kota Barat Kota Gorontalo. Hasil analisis multivariat juga menunjukkan bahwa umur merupakan faktor determinan kedua yang paling mempengaruhi terjadinya Hipertensi di wilayah kerja Puskesmas Kota barat dengan nilai $\rho$ $0,005(>0,1)$.

2. Faktor Obesitas

Presentase lansia obesitas yang menderita Hipertensi sebesar 80\% lebih tinggi dibandingkan dengan lansia yang tidak obesitas namun menderita Hipertensi (40\%). Hasil 
analisis dengan menggunakan chi square test didapatkan nilai $\chi 2$ hitung 7,287 dan nilai $\rho 0,007$. Dengan pemenuhan hipotesis bahwa $\chi 2$ hitung $>\chi 2$ tabel $(7,287>2.705)$ dan nilai $\rho<\alpha(0,007$ $<0,1)$, maka Ha diterima dan H0 ditolak, dengan demikian berarti obesitas merupakan faktor determinan penyakit Hipertensi pada lansia di Puskesmas Kota Barat Kota Gorontalo.

3. Faktor Aktivitas/Olahraga

Berdasarkan hasil penelitian bahwa lansia yang memiliki aktivitas kurang dan menderita Hipertensi lebih tinggi yakni sebesar 87,5\% dibandingkan dengan lansia yang memiliki aktivitas baik namun menderita Hipertensi yakni sebesar 41,4\%. Hasil analisis dengan menggunakan uji chi square didapatkan nilai $\chi 2$ hitung 8,991 dan nilai $\rho 0,003$. Dengan pemenuhan hipotesis bahwa $\chi 2$ hitung $>\chi 2$ tabel $(8,034>2,705)$ dan nilai $\rho<\alpha(0,003<0,1)$, maka Ha diterima dan $\mathrm{HO}$ ditolak, dengan demikian berarti aktivitas fisik/olahraga merupakan faktor determinan penyakit Hipertensi pada lansia di Puskesmas Kota Barat Kota Gorontalo.

4. Faktor Konsumsi Garam

Presentase lansia yang mengkonsumsi garam tidak sesuai memiliki presentase $100 \%$ menderita Hipertensi dibandingkan dengan lansia yang mengkonsumsi garam sesuai dan menderita Hipertensi (26,9\%). Hasil analisis dengan menggunakan uji chi square didapatkan nilai $\chi 2$ hitung 24,031 dan nilai $\rho 0,000$. Dengan pemenuhan hipotesis bahwa $\chi 2$ hitung $>\chi 2$ tabel $(24,031>2,705)$ dan nilai $\rho<\alpha(0,000<0,1)$, maka Ha diterima dan H0 ditolak, dengan demikian berarti konsumsi garam merupakan faktor determinan penyakit Hipertensi pada lansia di Puskesmas Kota Barat Kota Gorontalo. Hasil analisis multivariat juga menunjukkan bahwa konsumsi garam merupakan faktor determinan pertama yang paling mempengaruhi terjadinya Hipertensi di wilayah kerja Puskesmas Kota barat dengan nilai $\rho$ 0,005 $(>0,1)$.

5. Faktor Konsumsi Rokok

Presentase lansia yang merokok dan menderita Hipertensi sebesar 83,3\% lebih tinggi dibandingkan dengan lansia yang tidak merokok namun menderita Hipertensi (48,5\%). Hasil analisis dengan menggunakan uji chi square test didapatkan nilai $\chi 2$ hitung 4,381 dan nilai $\rho$ 0,036 . Dengan pemenuhan hipotesis bahwa $\chi 2$ hitung $>\chi 2$ tabel $(4,381>2,705)$ dan nilai $\rho<$ $\alpha(0,036<0,1)$, maka Ha diterima dan $\mathrm{H} 0$ ditolak dengan demikian berarti merokok merupakan faktor determinan penyakit Hipertensi pada lansia di Puskesmas Kota Barat Kota Gorontalo.

\section{PEMBAHASAN}

1. Faktor usia Sebagai Determinan Penyakit Hipertensi pada Lansia di Puskesmas Kota Barat Kota Gorontalo

Berdasarkan hasil penelitian dimana kelompok lansia yang berusia manula memiliki presentase tertinggi menderita Hipertensi dalam hal ini peneliti berkesimpulan bahwa semakin tua seseorang, maka lebih berisiko mengalami Hipertensi. Peneliti berasumsi bahwa hal tersebut disebabkan karena seiring bertambahnya usia seseorang, terjadi penurunan kemampuan organ-organ tubuh termasuk sistem kardiovaskuler dalam hal ini jantung dan pembuluh darah. Pembuluh darah menjadi lebih sempit dan terjadi kekakuan dinding pembuluh darah sehingga menyebabkan tekanan darah dapat meningkat. Hal ini sejalan dengan teori bahwa semakin meningkat umur seseorang maka risiko terkena Hipertensi sangatlah besar, hal ini terjadi karena pada umur tua arteri besar kehilangan kelenturan dan menjadi kaku sehingga darah yang dipaksa untuk melalui pembuluh darah yang sempit dari pada biasanya dan mengakibatkan naiknya tekanan darah. Tekanan darah tinggi banyak terjadi pada usia dewasa tengah yaitu diatas 40 tahun (Hartanti \& Mifbakhuddin, 2015). 
Tingginya Hipertensi sejalan dengan bertambahnya umur, disebabkan oleh perubahan struktur pada pembuluh darah besar, sehingga lumen menjadi sempit dan dinding pembuluh darah menjadi lebih kaku, sebagai akibat adalah meningkatnya tekanan darah sistolik. Dengan meningkatnya umur didapatkan kenaikan tekanan darah diastol rata-rata walaupun tidak begitu nyata juga terjadi kenaikan angka prevalensi Hipertensi tiap kenaikan kelompok dekade umur (Sartik, Tjekyan, \& Zulkarnain, 2017).

Hasil penelitian ini sejalan dengan penelitian sebelumnya dari Ningsih \& Indriani (2017) pada responden pekerja pasar Beringharjo Kota Yogyakarta, yang mendapatkan hasil bahwa usia berhubungan dengan kejadian Hipertensi $(\mathrm{p}=0,000)$, Odds Ratio $(\mathrm{OR}=15,706, \mathrm{CI} 95 \%$ $3,615-68,230$ ), artinya semakin tua seseorang akan berpeluang 15,7 kali mengalami Hipertensi yang makin berat.

2. Faktor Obesitas Sebagai Determinan Penyakit Hipertensi pada Lansia di Puskesmas Kota Barat Kota Gorontalo

Berdasarkan hasil analisis bahwa obesitas yang dialami seseorang dapat menyebabkan terjadinya Hipertensi. Hal ini disebabkan karena seseorang yang mengalami obseitas akan membutuhkan banyak darah untuk menyuplai oksigen dan makanan dalam jaringan tubuh, dengan demikian volume darah yang beredar dalam pembuluh darah semakin meningkat, kerja jantung juga akan semakin cepat akibatnya terjadilah peningkatan tekanan darah.

Obesitas dapat menimbulkan terjadinya Hipertensi melalui berbagai mekanisme, baik secara langsung maupun tidak langsung. Secara langsung obesitas dapat menyebabkan peningkatan cardiac output karena makin besar massa tubuh makin banyak pula jumlah darah yang beredar sehingga curah jantung ikut mening-kat. Sedangkan secara tidak langsung melalui perangsangan aktivitas sistem saraf simpatis dan Renin Angiotensin Aldosteron System (RAAS) oleh mediator-mediator seperti hormon, sitokin, adipokin, dsb. Salah satunya adalah hormon aldosteron yang terkait erat dengan retensi air dan natrium sehingga volume darah meningkat (Sulastri, 2012).

3. Faktor Aktivitas/Olahraga Sebagai Determinan Penyakit Hipertensi pada Lansia di Puskesmas Kota Barat Kota Gorontalo

Seseorang penderita Hipertensi yang melakukan aktivitas fisik/olahraga setiap hari dapat memperkecil resiko terjadinya Hipertensi, demikian pula sebaliknya bila seseorang tidak pernah atau jarang melakukan aktivitas fisik/olahraga setiap hari dapat meningkatkan resiko terjadinya Hipertensi.

Aktivitas fisik yang tinggi dapat mencegah atau memperlambat onset tekanan darah tinggi dan menurunkan tekanan darah pada pasien Hipertensi. Orang yang rajin melakukan olahraga seperti bersepeda, jogging dan aerobik secara teratur dapat memperlancar peredaran darah sehingga dapat menurunkan tekanan darah. Orang yang kurang aktif olahraga pada umumnya cenderung mengalami kegemukan. Olahraga juga dapat mengurangi atau mencegah obesitas serta mengurangi asupan garamke dalam tubuh. Garam akan keluar dri dalam tubuh bersama keringat. Melalui olahraga raga yang teratur (aktivitas fisik aerobik selama 30-45 menit/hari) dapat menurunkan tahanan perifer yang akan mencegah terjadinya Hipertensi (Prasetyo, 2015).

4. Faktor Konsumsi Garam Sebagai Determinan Penyakit Hipertensi pada Lansia di Puskesmas Kota Barat Kota Gorontalo

Berdasarkan analisis peneliti berkesimpulan bahwa dengan mengkonsumsi garam berlebihan dan tidak sesuai dengan diet rendah garam bagi penderita Hipertensi, dapat menyebabkan bertambah beratnya Hipertensi yang dialami. Semakin buruk perilaku konsumsi garam seseorang tingkat Hipertensi dapat bertambah makin berat. 
Peneliti berasumsi, hal tersebut disebabkan oleh asupan natrium dalam garam yang cukup tinggi akibat konsumsi yang berlebihan mengakibatkan pengecilan arteri sehingga jantung harus bekerja lebih keras untuk memompa darah melalui ruang arteri yang menyempit sehingga tekanan darah akan meningkat pula.

Sejalan dengan teori yang dikemukakan bahwa konsumsi garam yang berlebih menyebabkan konsentrasi natrium di dalam cairan ekstraseluler meningkat. Untuk menormalkannya cairan intraseluler ditarik ke luar, sehingga volume cairan ekstraseluler meningkat. Meningkatnya volume cairan ekstraseluler tersebut menyebabkan meningkatnya volume darah, sehingga berdampak kepada timbulnya Hipertensi. Karena itu disarankan untuk mengurangi konsumsi natrium/sodium. Sumber natrium/sodium yang utama adalah natrium klorida (garam dapur), penyedap masakan monosodium glutamate (MSG), dan sodium karbonat. Konsumsi garam dapur (mengandung iodium) yang dianjurkan tidak lebih dari 6 gram per hari, setara dengan satu sendok teh. Dalam kenyataannya, konsumsi berlebih karena budaya masakmemasak masyarakat kita yang umumnya boros menggunakan garam dan MSG (Santi, 2015).

Bagi penderita Hipertensi dianjurkan menjalani diet sesuai dengan kandungan garam/natrium, yakni : Diet rendah garam I (200-400 mg Na), untuk Hipertensi berat, dengan edema, asites, pada pengolahan masakannya tidak menambahkan garam dapur ; Diet rendah garam II (600-800 mg Na), untuk Hipertensi tidak terlalu berat, edema, asites, pada pengolahan masakannya boleh ditambahkan 1/2 sdt garam dapur (2 gram); Diet rendah garam III (1000-1200 $\mathrm{mg} \mathrm{Na}$ ) untuk Hipertensi ringan, pada pengolahan masakannya boleh ditambah dengan 1 sdt garam dapur (4 gram) (Hartono, 2014).

5. Faktor Merokok Sebagai Determinan Penyakit Hipertensi pada Lansia di Puskesmas Kota Barat Kota Gorontalo

Berdasarkan hasil penelitian, peneliti berasumsi bahwa kandungan zat-zat berbahaya yang terkandung dalam rokok yang dapat membuat jantung memompa lebih cepat dan lebih keras, akibatnya tekanan jantung dalam mengalirkan darah melalui pembuluh darah semakin kencang sehingga meningkatkan tekanan darah dan terjadi Hipertensi. Kandungan rokok yang paling berbahaya adalah nikotin.

Merokok merupakan faktor utama penyebab penyakit pembuluh darah jantung serta peningkatan tekanan darah. Seseorang menghisap rokok denyut jantungnya akan meningkat sampai $30 \%$. Rokok mengandung nikotin sebagai penyebab ketagihan dan merangsang pelepasan adrenalin sehingga kerja jantung lebih cepat dan kuat, akhirnya terjadi peningkatan tekanan darah (Purwanti, 2018).

\section{SIMPULAN DAN SARAN}

Temuian ini menyimpulkan bahwa faktor determinan yang berkorelasi paling kuat terhadap penyakit Hipertensi pada lansia di Puskesmas Kota Barat Kota Gorontalo adalah konsumsi rokok, diikuti dengan usia, kemudian diikuti oleh faktor-faktor yang lain yang menyebabkan timbulnya Hipertensi. Rokok menempati urutan penyebab utama untuk penyakit ini. Padahal perilaku merokok ini sebenarnya merupakan suatu hal yang dapat dihindari apabila sudah ada komitmen untuk berhenti merokok. Berbeda dengan usia yang akan semakin menua yang tidak bisa dihindari lagi. Apabila orang yang sudah lanjut usia, kemudian ditambah lagi dengan merokok dan tidak menerapkan pola hidup sehat yang lainnya, maka penyakit ini akan semakin beresiko mengintai setiap saat. 


\section{REFERENSI}

Ainun, A. S., Sidik, D., \& Rismayanti. (2014). Hubungan Gaya Hidup dengan Kejadian Hipertensi pada Mahasiswa di Lingkup Kesehatan Universitas Hasanuddin. UNHAS Repository. Retrieved from http://repository.unhas.ac.id/handle/123456789/10728

Azizah. (2011). Keperawatan Lanjut Usia Edisi 1. Yogyakarta: Graha Ilmu.

Budiman. (2013). Kapita Selekta Kuisioner Pengetahuan dan Sikap dalam Penelitian Kesehatan. Jakarta: Salemba Medika.

Buheli, K. L., \& Usman, L. (2019). Faktor Determinan Kepatuhan Diet Penderita Hipertensi. Jambura Health and Sport Journal, 1(1), 20-24. Retrieved from http://ejurnal.ung.ac.id/index.php/jhsj/article/view/2049

Fatmah. (2010). Gizi Usia Lanjut. Erlangga: Jakarta.

Harahap, R.A., Rochadi, R. K., \& Sarumpaet, S. (2017). Pengaruh Aktivitas fisik terhadap Kejadian Hipertensi pada Laki-Laki Dewasa Awal (18-40 tahun) di Wilayah Puskesmas Bromo Medan Tahun 2017. Jurnal Muara Sains, Teknologi, Kedokteran, dan Ilmu Kesehatan. 1(2). Retrieved from

https://journal.untar.ac.id/index.php/jmistki/article/download/951/882

Hartanti, M. P., \& Mifbakhuddin. (2015). Beberapa Faktor yang Berhubungan dengan Kejadian Hipertensi pada Petani. Jurnal Kesehatan Masyarakat Indonesia (JKMI), 10(1), 30-37.

Retrieved from https://jurnal.unimus.ac.id/index.php/jkmi/article/view/2375/2348

Hartono. (2014). Hipertensi The Silent Killer. Jakarta: Perhimpunan Hipertensi Indonesia.

Karim, N.S. (2018) Hubungan Aktivitas Fisik dengan Derajat Hipertensi pada Pasien Rawat Jalan di Wilayah Kerja Puskesmas Tugulandang Kabupaten Sitaro. Jurnal Universitas Sam Ratulangi, 6(1). Retrieved from

https://ejournal.unsrat.ac.id/index.php/jkp/article/download/19468/19019

Kemenkes RI. (2017). Sebagian Besar Penderita Hipertensi Tidak Menyadarinya. Jakarta: Kementerian Kesehatan Republik Indonesia.

. (2018) Riset Kesehatan Dasar (RISKESDAS) Tahun 2018. Jakarta: Kementerian Kesehatan Republik Indonesia.

Ningsih, D.L.R,. \& Indriani (2017). Faktor-faktor yang Berhubungan dengan Kejadian Hipertensi pada Pekerja Sektor Informal di Pasar Beringharjo Kota Yogyakarta. Skripsi, Universitas 'Aisyiyah Yogyakarta. Diakses dari http://digilib.unisayogya.ac.id/2689/

PKM Kota Barat. (2018). Prevalensi Hipertensi di Puskesmas Kota Barat, Puskesmas Kota Barat Kota Gorontalo. Gorontalo.

Prasetyo, D.A. (2015). Faktor-faktor yang Berhubungan dengan Kejadian Hipertensi pada Usia Dewasa Muda di Wilayah Puskesmas Sibela Surakarta. Skripsi, Fakultas Kedokteran Universitas Muhammadiyah Surakarta. Diakses dari http://eprints.ums.ac.id

Purwanti, R.T.P.A. (2018). Hubungan Kebiasaan Merokok dengan Terjadinya Hipertensi pada Pegawai CV. Lusindo Desa Sukadanau Cikarang Barat. Skripsi, Fakultas Kedokteran Universitas Muhammadiyah Surakarta. Diakses dari http://eprints.ums.ac.id

Santi, D.D. (2015). Hubungan Tingkat Konsumsi Garam terhadap Kejadian Hipertensi di Nagari Lunang Barat Wilayah Kerja Puskesmas Tanjung Beringin Kecamatan Lunang Kabupaten Pesisir Selatan Tahun 2014. Skripsi, Fakultas Keperawatan Universitas Andalas. Diakses dari http://scholar.unand.ac.id

Sari. (2017). Berdamai dengan Hipertensi. Jakarta: Bumi Medika.

Sartik, S., Tjekyan, R. S., \& Zulkarnain, M. (2017). Risk Factors And The Incidence Of Hipertension In Palembang. Jurnal Ilmu Kesehatan Masyarakat, 8(3), 180-191. 
https://doi.org/10.26553

Setyanda, Y.O.G., Sulastri, D., Lestari, D. (2015). Hubungan Merokok dengan Kejadian Hipertensi pada Laki-laki Usia 35-65 Tahun di Kota Padang. Skripsi, Fakultas Keperawatan Universitas Andalas. Diakses dari http://scholar.unand.ac.id

Sulastri. (2012). Hubungan Obesitas dengan Kejadian Hipetensi pada Masyarakat Etnik Minangkabau di Kota Padang. Skripsi, Fakultas Keperawatan Universitas Andalas. Diakses dari http://scholar.unand.ac.id

Udjianti. (2010). Keperawatan Kardiovaskular. Jakarta: Salemba Medika.

Widyanto dkk. (2013). Trend Disease (Trend Penyakit Saat Ini). Jakarta:Trans Info Media 